\title{
Uji aktivitas antifungi ekstrak etanol daun cabai jawa (Piper retrofractum) terhadap pertumbuhan candida albicans
}

\author{
Antifungal activity test of Piper retrofractum leaf ethanol extract on Candida albicans growth
}

\author{
EVI ROSYIDA SARI, ESTU RETNANINGTYAS NUGRAHENI \\ Jurusan D3 Farmasi, Fakultas Matematika dan Ilmu Pengetahuan Alam, Universitas Sebelas Maret. Jl. Ir. Sutami 36A Surakarta 57126, Surakarta
}

Manuskrip diterima: 9 April 2013. Revisi disetujui: 16 Agustus 2013.

\begin{abstract}
Sari ER, Nugraheni ER. 2013. Antifungal activity test of Piper retrofractum leaf ethanol extract on Candida albicans growth. Biofarmasi 13: 36-42. Candida albicans is a pathogenic microbe infecting vagina, thrush (fungal infection on mouth cavity) and paronichia (the presence of pus on nail pad). The less effective treatment system, and the incidence of toxicity on several antifungal lead to the selection of alternative medication (treatment) from the secondary metabolite compounds of flavonoid, alkaloid and saponin existing in java chili (Piper retrofractum Vahl) leaf. This research aimed to examine the antifungal activity of javanese chili (Piper retrofractum Vahl) leaf ethanol extract on Candida albicans, as well as to determine the antifungal properties of antifungal activity of javanese chili leaf ethanol extract. The extract was obtained by maceration using $70 \%$ ethanol. The ethanol extract obtained was 57.895 gram with the specimen of $7.61 \%(b / w)$. The result of phytochemical screening showed the presence of flavonoid, saponin and alkaloid compounds, all of those were antifungal. The examination of antifungal activity of javanese chili leaf ethanol extract was performed by using a diffusion method and the concentration series of $10-100 \%$ by adding DMSO as a diluent and it was performed with 3 times of repetition. The result of DDH was analyzed using CRD (Completely Random Design) with one-way ANOVA at a confidence interval of 95\% and LSD to find out the significant difference between the concentration series. The result of antifungal activity examination showed that the ethanol extract at $40 \%$ concentration provided more effective DDH on C. albicans of 5.54 $\pm 0,64 \mathrm{~mm}$. The result of examination was processed by using one-way ANOVA and LSD indicating a significant difference $(\mathrm{p}<0.05)$ between the concentration series. At $40 \%$ concentration, the antifungal examination was performed on $C$. albicans. The result showed that the javanese chili leaf ethanol extract was a fungiostatic against the tested fungus.
\end{abstract}

Keywords: Antifungal, Candida albicans, javanese chili (Piper retrofractum Vahl) leaf, DDH

\section{PENDAHULUAN}

Candida albicans merupakan spesies jamur yang paling sering menyebabkan infeksi jamur pada manusia. Apabila ditinjau dari insidennya, infeksi C. albicans meningkat 87\% dalam kurun waktu 9 tahun, yaitu dari tahun 1980 sampai 1989. Infeksi C. albicans pada tubuh manusia dapat meningkat apabila sistem pertahanan tubuh menurun, permukaan kulit yang lembap akibat terpapar oleh keringat, air, urin, atau saliva, serta konsumsi obat antibiotik oral secara rutin. Berdasarkan laporan Magdalena (2009), ditemukan C. albicans dalam jumlah besar pada saluran pencernaan setelah pemberian antibiotika oral, misalnya tetrasiklin. Candida albicans dapat menyebar ke organ lain apabila imunitas seluler menurun.

Saat ini, obat-obatan antifungi yang tersedia di pasaran semakin banyak. Penggunaan beberapa obat antifungi yang kurang efektif, serta terjadinya toksisitas terhadap beberapa produk antifungi yang tersedia mendorong penelitian untuk mencari senyawa yang bersifat antifungi dari tanaman. Hal ini dikarenakan penggunaan obat yang berasal dari bahan alam diyakini dapat menimbulkan efek samping yang minimal dan efek terapeutik maksimal. Dari penelitian sebelumnya, diperoleh hasil bahwa serasah Piper betle
Linn. memiliki aktivitas antibiotik (Nurkanto 2010). Dari penelitian tersebut, disebutkan juga bahwa tanaman dari famili Piperaceae merupakan tanaman yang dikenal luas telah digunakan sebagai bahan obat dan tersebar luas di hutan hujan tropis Indonesia. Tanaman obat yang dipilih sebagai alternatif antifungi untuk mengatasi infeksi Candida albicans diantaranya cabai jawa (Piper retrofractum Vahl) dengan bagian tanaman yang dimanfaatkan berupa daun. Daun cabai jawa diduga memiliki aktivitas antifungi terhadap C. albicans, sehingga mendorong untuk dilakukan penelitian lebih lanjut tentang aktivitas antifungi dari ekstrak tanaman tersebut yang meliputi daya hambat dan jenis hambatan. Selain itu, diharapkan juga dapat dilihat lebih lanjut kandungan senyawa aktif yang terkandung dalam ekstrak daun cabai jawa (Amalia et al. 2011).

Penelitian ini bertujuan untuk mengetahui aktivitas antifungi dari ekstrak etanol daun cabai jawa $(P$. retrofractum) terhadap pertumbuhan jamur $C$. albicans, menentukan sifat antifungi ekstrak etanol daun cabai jawa terhadap pertumbuhan jamur $C$. albicans, dan mengetahui kandungan kimia yang terdapat dalam ekstrak etanol daun cabai jawa yang berperan sebagai antifungi. 


\section{BAHAN DAN METODE}

\section{Waktu dan tempat penelitian}

Isolasi dan pemurnian senyawa pada penelitian ini dilakukan di Laboratorium Kimia Dasar, FMIPA, Universitas Sebelas Maret, Surakarta dan Laboratorium Pusat MIPA, Universitas Sebelas Maret, Surakarta. Determinasi jenis tumbuhan dilakukan di Bagian Biologi, Fakultas Farmasi, Universitas Gadjah Mada, Yogyakarta dan Laboratorium Morfologi Sistematik Tumbuhan, Universitas Setia Budi, Surakarta. Analisis spektroskopi UV dilakukan di Laboratorium Kimia Dasar, FMIPA, Universitas Sebelas Maret, Surakarta. Analisis spektroskopi inframerah dilakukan di Laboratorium Kimia Organik FMIPA UGM, Yogyakarta, sedangkan analisis ${ }^{13} \mathrm{C}$ NMR APT, ${ }^{1} \mathrm{H}$ NMR, dan NMR dua dimensi dilakukan di Pusat Penelitian Kimia, LIPI Serpong, Tangerang Selatan. Penelitian ini dilakukan selama 11 bulan dari bulan Mei 2009 sampai Maret 2010.

\section{Alat dan bahan}

Peralatan yang digunakan dalam penelitian ini meliputi tabung reaksi, Erlenmeyer $50 \mathrm{~mL}$ dan $250 \mathrm{~mL}$, gelas ukur $10 \mathrm{~mL}$ dan $50 \mathrm{~mL}$, gelas beker $5 \mathrm{~mL}$, cawan petri, pipet volum $2 \mathrm{~mL}$, oven (Celculture $\mathrm{CO}_{2}$ Incubator), neraca timbang, incubator (Incubator Hotcold- $M$ ), spatula logam, pelubang gabus (perforator), pipet mikro $100 \mu \mathrm{l}$, autoklaf, shaker, batang drigalsky, Laminar Air Flow (LAF) (SWCJ JB Vertikal), jarum ose, tip kuning $200 \mu \mathrm{l}$, rotary evaporator (RE 200B), waterbath (Haake DL 30), lemari pendingin, dan jangka sorong.

Sementara itu, bahan yang digunakan yaitu daun cabai jawa yang diambil dari Desa Pulosari, Kecamatan Papar, Kabupaten Kediri, Jawa Timur. Bahan kimia yang digunakan yaitu pelarut organik etanol 70\% (Brataco Chemika), etanol 96\% (Pro-Analisis), akuades, dimetil sulfoksida (DMSO), SDA (Sabouraud Dextrose Agar) (E. Merck), antibiotik kloramfenikol, antijamur kandistatin, $\mathrm{HCl} 2 \mathrm{~N}$, serbuk Mg, larutan amil alkohol, gelatin, dan pereaksi Wagner. Jamur yang digunakan adalah Candida albicans yang diperoleh dari Laboratorium Mikrobiologi, Fakultas Kedokteran, Universitas Sebelas Maret, Surakarta.

\section{Metodologi penelitian}

Penelitian ini menggunakan metode eksperimental dalam laboratorium. Metode yang digunakan untuk mengekstraksi kandungan kimia dalam daun cabai jawa adalah metode maserasi dengan menggunakan pelarut etanol 70\%. Ekstrak etanol daun cabai jawa yang diperoleh digunakan untuk pengujian aktivitas antijamur. Ekstrak etanol daun cabai jawa yang mempunyai aktivitas antijamur selanjutnya dilakukan skrining fitokimia. Ekstrak etanol yang memiliki aktivitas antijamur tertinggi dilakukan uji daya hambat terhadap jamur uji C. albicans dengan kontrol antifungi nistatin.

\section{Cara kerja}

\section{Determinasi tanaman}

Tanaman yang digunakan dalam penelitian ini adalah daun cabai jawa (Piper retrofractum Vahl). Determinasi dilakukan berdasarkan pengamatan ciri morfo-fisiologis tumbuhan.

\section{Pembuatan serbuk simplisia}

Daun yang sudah dipanen selanjutnya dicuci bersih dengan air mengalir, ditiriskan, dan dikeringkan dengan menggunakan oven pada suhu $50^{\circ} \mathrm{C}$ selama $\pm 2 x 24$ jam. Selanjutnya, daun yang sudah kering dihancurkan dengan menggunakan blender hingga berbentuk serbuk.

\section{Ekstraksi maserasi serbuk simplisia dengan pelarut etanol}

Serbuk simplisia sebanyak 760 gram diekstraksi dengan metode maserasi (perendaman bahan) menggunakan pelarut etanol 70\% sebanyak 4,5 liter. Maserasi dilakukan selama 4x24 jam dengan dilakukan pengadukan beberapa kali. Ekstrak yang diperoleh kemudian diuapkan pelarutnya secara vakum menggunakan rotary evaporator dengan suhu $50^{\circ} \mathrm{C}$ dan kecepatan putar 5 rpm sampai berbentuk ekstrak kental. Apabila masih terdapat sisa pelarut maka ekstrak dikeringanginkan dengan menggunakan waterbath hingga seluruh pelarut menguap dan diperoleh ekstrak etanol daun cabai jawa.

\section{Pembuatan seri konsentrasi ekstrak etanol daun cabai jawa}

Ekstrak kental daun cabai jawa dibuat 10 seri konsentrasi (10-100\%) dengan menggunakan pelarut dimetil sulfoksida (DMSO). Setiap seri konsentrasi dibuat dengan menambahkan pelarut DMSO ke dalam beberapa gram ekstrak kental daun cabai jawa, sampai volumenya 2 mL. Jumlah ekstrak yang digunakan dalam penelitian ditunjukkan dalam Tabel 1.

\section{Pengujian aktivitas antijamur ekstrak etanol}

Seri konsentrasi ekstrak etanol daun cabai jawa yang sudah dibuat kemudian diuji aktivitas antijamurnya untuk menentukan ekstrak yang aktif.

Persiapan alat dan bahan. Pada pengujian aktivitas antijamur diperlukan persiapan awal yaitu mensterilkan alat dan bahan yang akan digunakan, meliputi cawan petri, gelas ukur, tabung reaksi, gelas beker, tip kuning, pipet, Erlenmeyer, batang pengaduk, akuades, dan pelarut DMSO. Semua alat dan bahan tersebut disterilkan dalam autoklaf dengan suhu $121^{\circ} \mathrm{C}$ dan tekanan 1 atm selama 15 menit.

Tabel 1. Jumlah ekstrak yang digunakan dalam pembuatan stok konsentrasi ekstrak daun cabai jawa

\begin{tabular}{lcc}
\hline $\begin{array}{l}\text { Konsentrasi ekstrak } \\
(\%, \mathbf{b} / \mathbf{v})\end{array}$ & $\begin{array}{c}\text { Berat ekstrak etanol daun } \\
\text { cabai jawa }(\mathbf{g})\end{array}$ & $\begin{array}{c}\text { DMSO } \\
(\mathbf{m L})\end{array}$ \\
\hline 10 & 0,2 & ad 2 \\
20 & 0,4 & ad 2 \\
30 & 0,6 & ad 2 \\
40 & 0,8 & ad 2 \\
50 & 1,0 & ad 2 \\
60 & 1,2 & ad 2 \\
70 & 1,4 & ad 2 \\
80 & 1,6 & ad 2 \\
90 & 1,8 & ad 2 \\
100 & 2,0 & ad 2 \\
\hline
\end{tabular}


Pembuatan media Sabouraud Dextrose Agar (SDA). Media agar dibuat dengan melarutkan 65 gram SDA ke dalam $1 \mathrm{~L}$ akuades panas. Serbuk SDA dilarutkan sedikit demi sedikit hingga menjadi larutan yang homogen kemudian ditambahkan suspensi antibiotik kloramfenikol sebanyak 0,1 mL tiap $50 \mathrm{~mL}$ media. Kemudian media disterilisasi dalam autoklaf pada suhu $121^{\circ} \mathrm{C}$ selama 20 menit. Media yang sudah disterilisasi dituang ke dalam tabung reaksi sebanyak $5 \mathrm{~mL}$ untuk dibuat agar miring dan digunakan untuk pembenihan jamur uji.

Penyediaan jamur uji. Jamur uji dibiakkan dalam agar miring yang telah disiapkan kemudian diinkubasi pada suhu $24-27^{\circ} \mathrm{C}$.

Penyediaan suspensi jamur uji. Jamur berumur 4 hari (untuk metode penanaman gores silang) diambil sebanyak 1 ose dan disuspensikan ke dalam $\mathrm{NaCl}$ 0,9\% steril sebanyak $10 \mathrm{~mL}$. Suspensi jamur selanjutnya diinkubasi pada suhu kamar dengan cara di-shaker pada kecepatan putaran 120 rpm selama 24 jam. Suspensi jamur yang semula jernih akan berubah menjadi keruh, yang menunjukkan adanya pertumbuhan jamur setelah masa inkubasi, kemudian suspensi jamur diukur densitasnya dengan menggunakan spektrofotometer pada panjang gelombang $530 \mathrm{~nm}$ hingga diperoleh adsorbansi 0,5.

Pengujian aktivitas antijamur. Pengujian aktivitas antijamur bertujuan untuk mengetahui aktivitas penghambatan ekstrak daun cabai jawa terhadap $C$. albicans dengan menggunakan metode difusi agar (dengan menggunakan lubang/metode perforasi). Uji aktivitas antijamur dilakukan dengan menggunakan media SDA yang sudah disterilisasi dengan autoklaf selama 15 menit pada suhu $121^{\circ} \mathrm{C}$ dan tekanan 1 atm. Media SDA didiamkan hingga suhu mencapai kisaran $40-50^{\circ} \mathrm{C}$, kemudian media dituang ke dalam cawan petri sebanyak 20 mL. Media SDA didinginkan pada suhu ruang hingga memadat, lalu dilakukan penanaman jamur uji dengan menggunakan metode spread plate.

Penanaman jamur uji dilakukan dengan menggunakan metode spread plate melalui tahapan-tahapan sebagai berikut. Suspensi jamur yang sudah dibuat sebelumnya diambil sebanyak $50 \mu$ dengan menggunakan mikropipet kemudian diteteskan pada bagian tengah permukaan agar yang sudah memadat. Tetesan suspensi jamur tersebut kemudian diratakan dengan menggunakan batang drigalsky steril dengan sesekali cawan petri diputar agar penyebaran jamur uji lebih merata.

Media padat yang sudah bercampur dengan jamur uji dibuat sumuran dengan menggunakan pelubang gabus (perforator) berdiameter $6 \mathrm{~mm}$. Pada sumuran tersebut dilakukan berbagai uji, untuk mengetahui aktivitas penghambatan larutan uji terhadap jamur uji serta seri konsentrasi ekstrak etanol daun cabai jawa. Larutan uji yang digunakan adalah kontrol pelarut DMSO, etanol 70\%, dan nistatin 1000 unit. Masing-masing larutan uji dari seri konsentrasi ekstrak diinjeksikan sebanyak $20 \mu \mathrm{l}$ ke dalam lubang sumuran (hold), kemudian diinkubasi selama 2x24 jam pada suhu $24-25^{\circ} \mathrm{C}$ dalam inkubator. Pengamatan hasil inkubasi dilakukan terhadap adanya koloni jamur uji dan zona bening di sekitar sumuran yang menandakan adanya efek penghambatan larutan uji dan seri konsentrasi ekstrak terhadap jamur uji. Zona bening yang ada merupakan zona hambat pertumbuhan jamur uji, dapat diukur diameternya dengan menggunakan jangka sorong.

Untuk penentuan uji daya hambat atau daya bunuh suatu ekstrak yang memiliki efek penghambatan paling optimal terhadap jamur uji, dilakukan dengan mengambil 1 ose bagian zona hambat terbesar yang terbentuk dari aktivitas penghambatan suatu seri konsentrasi ekstrak, kemudian ditanam dalam media SDA dengan menggunakan metode penanaman gores silang. Sebagai pembanding, dapat ditanam zona bening yang terbentuk dari produk obat antijamur (nistatin) dengan menggunakan metode yang sama dan dilakukan inkubasi selama 5 hari pada suhu $24-25^{\circ} \mathrm{C}$ dalam inkubator. Hasil pengamatan berupa ada atau tidak adanya koloni jamur yang terbentuk dalam media SDA. Apabila hasil menunjukkan terdapat koloni jamur yang terbentuk maka aktivitas penghambatan suatu seri konsentrasi ekstrak yang memiliki zona bening terbesar hanya bersifat fungiostatik, artinya ekstrak hanya mampu menghambat pertumbuhan jamur uji, bukan membunuh jamur uji.

\section{Skrining fitokimia/uji tabung ekstrak etanol daun cabai jawa}

Uji saponin. Ekstrak dilarutkan dalam akuades lalu dipanaskan dengan penangas air. Setelah dingin, larutan dalam tabung reaksi dikocok kuat-kuat selama 30 detik. Hasil positif ditunjukkan dengan terbentuknya busa yang konsisten selama beberapa menit dan dengan penambahan 1 tetes $\mathrm{HCl}$ encer masih terbentuk busa.

Ujiflavonoid. Ekstrak ditambahkan dengan serbuk Mg dan HCl $1 \mathrm{~N}$ kemudian dipanaskan di atas penangas air. Setelah itu, ekstrak ditambahkan dengan amil alkohol dan dikocok hingga tercampur rata. Hasil positif ditandai dengan tertariknya warna kuning-merah pada lapisan alkohol.

Uji alkaloid. Ekstrak ditambahkan dengan $\mathrm{HCl} 2 \mathrm{~N}$ sampai $5 \mathrm{~mL}$ di dalam tabung reaksi, dikocok, kemudian dipanaskan di atas penangas air sampai mendidih. Dari hasil pemanasan, terbentuk dua lapisan. Lapisan bening (lapisan atas) diambil kemudian ditetesi dengan pereaksi Wagner. Hasil positif ditunjukkan oleh terbentuknya endapan berwarna cokelat.

\section{Analisis data}

Dari uji aktivitas antijamur pada seri konsentrasi ekstrak dan larutan uji didapatkan data diameter zona hambat dari seri konsentrasi ekstrak tertentu. Dalam uji aktivitas antifungi ekstrak etanol daun cabai jawa terhadap pertumbuhan $C$. albicans, juga dilakukan skrining fitokimia, dan diperoleh data golongan senyawa tertentu yang diduga bersifat sebagai antifungi. Pada tahap pengujian aktivitas antijamur ini diketahui ekstrak yang menunjukkan aktivitas antijamur tertinggi berdasarkan diameter zona hambat. Ekstrak dengan aktivitas antijamur tertinggi tersebut selanjutnya dilakukan uji daya hambat. Data diameter zona hambat dari variasi konsentrasi ekstrak hasil pengujian aktivitas antijamur dilakukan analisis data dengan One-Way ANOVA dengan taraf kepercayaan 95\%. 


\section{HASIL DAN PEMBAHASAN}

\section{Determinasi sampel}

Hasil determinasi menunjukkan bahwa daun yang diteliti merupakan jenis Piper retrofractum Vahl.

\section{Preparasi bahan}

Daun cabai jawa basah yang sudah dipanen sebanyak 1550 gram dikeringkan dalam oven pada suhu $50^{\circ} \mathrm{C}$ selama 2 hari. Pengeringan dilakukan pada suhu $<50^{\circ} \mathrm{C}$, karena pengeringan yang dilakukan pada suhu yang terlalu tinggi dalam waktu yang lama dapat menyebabkan simplisia yang diperoleh ditumbuhi kapang (Sirait 1985). Pengeringan simplisia dalam oven bertujuan untuk mempercepat penghilangan air dan mendapatkan bahan dengan kadar air yang rendah, sehingga bahan tidak menjadi busuk selama proses penyimpanan. Dari proses pengeringan tersebut diperoleh simplisia sebanyak 760 gram.

Simplisia kemudian dihaluskan dengan menggunakan blender, sehingga diperoleh serbuk daun cabai jawa. Simplisia dihancurkan dengan tujuan untuk memperluas luas permukaan jaringan tanaman agar sel yang mengandung senyawa yang berpotensi sebagai antijamur dapat diikat oleh pelarut dan senyawa tersebut dapat larut sebanyak mungkin dalam pelarut. Serbuk daun cabai jawa selanjutnya dilakukan ekstraksi dengan metode maserasi.

\section{Maserasi simplisia}

Serbuk daun cabai jawa diekstraksi dengan metode maserasi (perendaman bahan) menggunakan pelarut etanol $70 \%$ selama 4x24 jam sambil beberapa kali diaduk. Maserasi dipilih karena ekstraksi ini tidak melibatkan pemanasan, sehingga perubahan-perubahan senyawa dapat dihindari. Selain itu, proses maserasi juga mempunyai keuntungan dibandingkan dengan metode lain, yaitu dengan metode maserasi akan diperoleh ekstrak dalam jumlah banyak serta terhindar dari perubahan senyawasenyawa tertentu akibat pemanasan (Pratiwi 2008 dalam Kusuma 2010).

Maserasi berupa serbuk bertujuan untuk memperluas permukaan, sehingga interaksi pelarut dengan senyawa yang akan diambil lebih efektif dan senyawa dapat terekstrak sempurna. Pengadukan secara berkala selama proses maserasi bertujuan untuk menghindari mengendapnya serbuk, sehingga dapat mempersulit pelarut untuk menembus bahan dan mengakibatkan senyawasenyawa aktif yang terkandung dalam bahan tidak dapat terekstrak secara sempurna karena serbuk simplisia yang digunakan dalam jumlah banyak. Etanol 70\% dipilih sebagai pelarut dalam proses maserasi karena etanol merupakan salah satu pelarut yang tidak toksik/tidak beracun, selain itu juga mempunyai kemampuan dapat melarutkan hampir semua metabolit sekunder yang terkandung dalam simplisia, sehingga diharapkan senyawasenyawa yang bersifat antijamur dapat terekstrak dalam etanol (Depkes RI 1986).

Maserat yang diperoleh selanjutnya dipekatkan dengan menggunakan rotary evaporator. Tujuan digunakan rotary evaporator adalah untuk memisahkan metabolit sekunder dengan pelarut etanol, sehingga diperoleh ekstrak kental yang mengandung senyawa-senyawa aktif sebagai antifungi. Dari proses ekstraksi metode maserasi dihasilkan ekstrak etanol kental berwarna hijau kecokelatan sebanyak 57,895 gram dengan rendemen 7,61\%. Ekstrak kental yang diperoleh dari ekstraksi maserasi ini, kemudian dilakukan uji aktivitas antijamur.

\section{Pengujian aktivitas antijamur ekstrak etanol}

Ekstrak etanol kental yang didapatkan dari ekstraksi maserasi, kemudian dilakukan pengujian aktivitas antijamur untuk mengetahui apakah ekstrak etanol mempunyai aktivitas antijamur atau tidak. Uji aktivitas antijamur ekstrak etanol dilakukan terhadap jamur $C$. albicans. Penelitian ini menggunakan metode difusi agar dengan metode penanaman jamur spread plate. Teknik penanaman spread plate dilakukan dengan tujuan supaya jamur uji dapat tersebar merata dalam media agar.

Semua peralatan dan media yang digunakan harus dalam kondisi steril. Proses sterilisasi dilakukan dengan sterilisasi basah menggunakan autoklaf pada suhu $121^{\circ} \mathrm{C}$ selama 30 menit (untuk peralatan) atau 15 menit (untuk media). Proses pelaksanaan uji juga dilakukan secara aseptis di dalam Laminar Air Flow (LAF) yang telah dipapari UV terlebih dahulu selama 1-2 jam sebelum digunakan serta disemprot dengan alkohol 70\% sebagai disinfektan.

Ekstrak etanol dibuat dalam beberapa konsentrasi dengan melarutkannya dalam pelarut dimetil sulfoksida (DMSO). DMSO digunakan sebagai kontrol pelarut yang tidak memiliki aktivitas biologi, karena DMSO merupakan pelarut polar aprotik, tidak berwarna, serta dapat melarutkan senyawa polar dan nonpolar yang mempunyai rentang yang luas dari pelarut organik seperti halnya air. DMSO memiliki titik didih yang tinggi sehingga menguap secara perlahan pada tekanan udara normal dan titik bekunya tetap tinggi, selain itu DMSO tidak aktif sebagai antijamur yang telah dilakukan dan dibuktikan dalam penelitian Harliana (2006).

Metode difusi dipilih sebagai metode yang digunakan sebagai uji aktivitas antijamur karena metode ini memberikan akurasi yang tinggi dan lebih mudah mengukur luas daerah hambat yang terbentuk akibat efek penetrasi senyawa aktif sampai ke bawah media agar. Pada media agar dibuat lubang sumuran dengan diameter $6 \mathrm{~mm}$, kemudian diinjeksikan ekstrak etanol dengan berbagai seri konsentrasi sebanyak $20 \mu \mathrm{l}$ pada tiap lubang sumuran, sehingga dapat diketahui aktivitas antijamur yang dimiliki pada setiap seri konsentrasi yang dibuat yang ditunjukkan dengan diameter zona bening.

Hasil pengujian aktivitas antijamur ekstrak etanol ditunjukkan pada Tabel 2, yang ditunjukkan dengan adanya diameter zona hambat terhadap jamur uji. Berdasarkan hasil pada Tabel 2 dapat diketahui bahwa ekstrak etanol daun cabai jawa mempunyai aktivitas antijamur sedang terhadap C. albicans. Pada Tabel 2 juga dapat diketahui bahwa aktivitas antifungi ekstrak etanol daun cabai jawa paling optimum pada konsentrasi 40\%. Diameter zona hambat tidak selalu naik sebanding dengan naiknya konsentrasi ekstrak etanol daun cabe jawa, kemungkinan ini terjadi karena perbedaan kecepatan difusi senyawa 
antifungi pada media SDA. Kecepatan difusi tersebut menjadi salah satu penyebab dikarenakan dengan semakin besar konsentrasi ekstrak etanol maka viskositas/ kekentalan ekstrak. juga semakin besar (Harliana 2006).

Dari Gambar 1 dilakukan analisis statistik sehingga diketahui bahwa hasil paling optimum diperoleh pada konsentrasi $40 \%$. Diameter zona hambat tidak selalu meningkat sebanding dengan meningkatnya konsentrasi ekstrak etanol daun cabai jawa, hal ini diduga terjadi akibat adanya perbedaan kecepatan difusi senyawa antifungi pada media SDA. Kecepatan difusi tersebut menjadi salah satu penyebab bahwa dengan semakin besar konsentrasi ekstrak etanol maka terdapat perbedaan daya hambat antar konsentrasi ekstrak terhadap jamur uji. Metode analisis yang digunakan adalah analisis statistik parametrik OneWay ANOVA. Sebelum dilakukan analisis data dengan uji ANOVA, data terlebih dahulu dilakukan uji normalitas dan homogenitas data. Dari hasil uji normalitas menggunakan uji Kolmogorov-Smirnov didapatkan nilai signifikansi diameter hambat $C$. albicans $0,951(\mathrm{p}>0,05)$ yang artinya data terdistribusi normal, kemudian data diuji homogenitasnya. Dari hasil uji homogenitas diperoleh signifikansi sebesar 0,450 ( $>>0,05)$ yang artinya bahwa varian data sudah homogen. Dari hasil tersebut maka pada data daya hambat bakteri dapat dilakukan pengujian lebih lanjut dengan menggunakan uji One-Way ANOVA. Pengaruh adanya batas maksimum konsentrasi ekstrak etanol yang terdapat dalam tiap sumuran dapat diketahui dengan analisis data One-Way ANOVA. Dari hasil tersebut menunjukkan bahwa mulai dari konsentrasi ekstrak 10\% untuk tiap sumuran sampai konsentrasi ekstrak 70\% untuk tiap sumuran berpengaruh dalam menghambat pertumbuhan jamur $C$. albicans yang ditandai dengan beda nyata yang signifikan $(\mathrm{p}<0,05)$.

Hasil yang diperoleh menunjukkan bahwa adanya batas maksimum konsentrasi ekstrak etanol dalam menghambat pertumbuhan $C$. albicans selanjutnya dianalisis lebih lanjut dengan uji LSD untuk mengetahui konsentrasi yang berbeda nyata dan tidak berbeda nyata pengaruhnya terhadap diameter daya hambat ekstrak. Dari hasil uji LSD dibuat tabel yang menunjukkan perbedaan pengaruh tiap konsentrasi ekstrak yang disajikan pada Tabel 3.

Berdasarkan Tabel 3 dapat diketahui bahwa konsentrasi ekstrak 40\% lebih optimal dalam menghambat pertumbuhan jamur $C$. albicans. Pernyataan ini didukung oleh hasil pada Tabel 3 bahwa pada konsentrasi 40\% menunjukkan notasi huruf yang berbeda pada hampir seluruh konsentrasi yang berarti konsentrasi ekstrak 40\% memiliki diameter daya hambat yang berbeda nyata terhadap hampir keseluruhan konsentrasi ekstrak etanol daun cabai jawa.

Pengujian aktivitas antijamur ekstrak etanol daun cabai jawa terhadap pertumbuhan $C$. albicans, menggunakan salah satu produk obat antifungi paten sebagai kontrol/pembanding yaitu nistatin. Nistatin merupakan antifungi yang efektif bekerja pada khamir dari genus Candida (Ridawati et al. 2011). Nistatin merupakan salah satu antibiotik turunan polien yang dapat menghambat pertumbuhan jamur dengan menyerang ergosterol, suatu komponen membran jamur
C. albicans, tetapi tidak menghambat pertumbuhan bakteri karena membran bakteri tidak mengandung ergosterol (Muriana et al. 2011). Proses infeksi $C$. albicans pada tubuh manusia, bermula dari dinding sel dari C. albicans yang melekat pada sel kulit. Dinding sel C. albicans terdiri dari enam lapisan dari luar ke dalam, yaitu fibrillar layer, mannoprotein, $\beta$-glucan, $\beta$-glucanchitin, mannoprotein, dan membran plasma. Perlekatan lapisan dinding sel melibatkan ligan dan reseptor pada permukaan sel yang akan diserang, sehingga terjadi perubahan bentuk dari khamir menjadi filamen yang kemudian diikuti dengan pembentukan lapisan biofilm. Lapisan biofilm tersebut digunakan $C$. albicans untuk mempertahankan diri dari obat-obatan antifungi.

Pengujian aktivitas antijamur ekstrak etanol daun cabai jawa tersebut merupakan pengujian pada tahap awal. Ekstrak etanol daun cabai jawa yang positif memiliki aktivitas antijamur dengan daerah zona hambat yang besar selanjutnya dilakukan pengujian daya hambat atau daya bunuh.

Tabel 2. Hasil uji aktivitas antijamur ekstrak etanol daun cabai jawa dan kontrol terhadap jamur Candida albicans dengan metode difusi agar (perforasi)

\begin{tabular}{lc}
\hline Konsentrasi & $\begin{array}{c}\text { Daerah Diameter Hambat (DDH) } \\
\text { terhadap pertumbuhan C. albicans }\end{array}$ \\
\hline $10 \%$ & $2,11 \pm 0,45$ \\
$20 \%$ & $2,97 \pm 0,93$ \\
$30 \%$ & $4,39 \pm 0,45$ \\
$\mathbf{4 0 \%}$ & $5,54 \pm 0,64$ \\
$50 \%$ & $4,89 \pm 1,02$ \\
$60 \%$ & $3,96 \pm 0,36$ \\
$70 \%$ & $3,48 \pm 0,59$ \\
$80 \%$ & $3,17 \pm 0,58$ \\
$90 \%$ & $2,76 \pm 0,57$ \\
$100 \%$ & $2,04 \pm 0,56$ \\
Kontrol nistatin & 8,59 \\
Kontrol DMSO & 0 \\
Kontrol etanol 70\% & 0 \\
\hline Ketangan: Hasi
\end{tabular}

Keterangan: Hasil pengujian 3 kali pengulangan

Tabel 3. Notasi LSD pengaruh ekstrak etanol daun cabai jawa terhadap jamur uji Candida albicans

\begin{tabular}{lc}
\hline Konsentrasi & $\begin{array}{c}\text { Diameter Daya Hambat (DDH) } \\
\text { Candida albicans (mm) }\end{array}$ \\
\hline $10 \%$ & $2,11^{\mathrm{a}}$ \\
$20 \%$ & $2,97^{\mathrm{abg}}$ \\
$30 \%$ & $4,39^{\mathrm{c}}$ \\
$\mathbf{4 0 \%}$ & $\mathbf{5 , 5 4 ^ { \mathrm { d } }}$ \\
$50 \%$ & $4,89^{\mathrm{cd}}$ \\
$60 \%$ & $3,96^{\mathrm{bci}}$ \\
$70 \%$ & $3,48^{\mathrm{bc}}$ \\
$80 \%$ & $3,17^{\mathrm{abh}}$ \\
$90 \%$ & $2,77^{\mathrm{ab}}$ \\
$100 \%$ & $2,04^{\mathrm{aeg}}$ \\
\hline
\end{tabular}

Keterangan: Angka yang diikuti dengan notasi huruf yang sama tidak berbeda nyata pada uji LSD. 


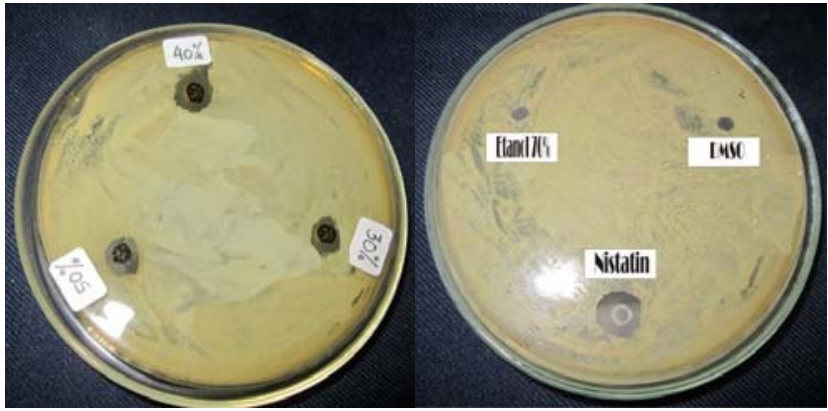

Gambar 1. Diameter daya hambat terbesar ekstrak etanol daun cabai jawa

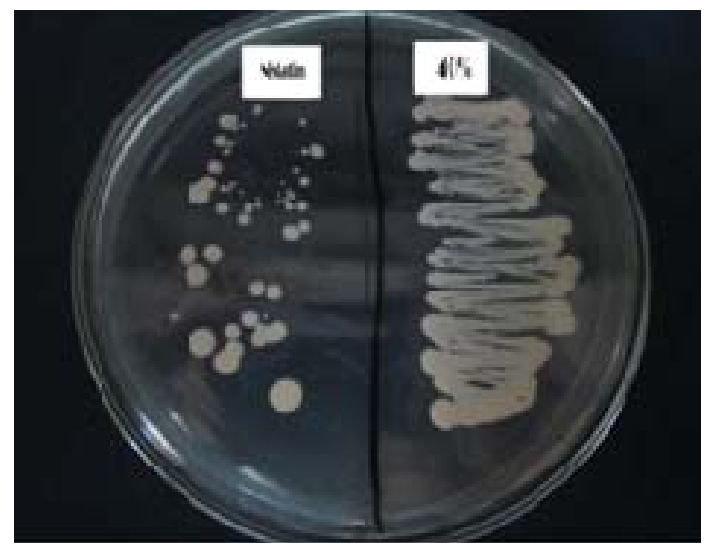

Gambar 2. Daya hambat nistatin dan konsentrasi ekstrak etanol daun cabai jawa $40 \%$ terhadap pertumbuhan C. albicans

\section{Penentuan daya hambat ekstrak etanol daun cabai jawa dan nistatin}

Uji daya hambat atau daya bunuh merupakan suatu penentuan apakah ekstrak etanol daun cabai jawa yang memiliki aktivitas antijamur terbesar dan antifungi nistatin memiliki kemampuan membunuh jamur uji atau hanya mampu menghambat pertumbuhan jamur uji. Ekstrak etanol daun cabai jawa yang memiliki daerah zona bening terbesar adalah pada konsentrasi $40 \%$ (b/v).

Dari hasil pengujian, bagian zona bening ekstrak etanol konsentrasi $40 \%$ beserta antijamur nistatin ditanam kembali pada media agar SDA dan tumbuh koloni jamur lagi. Hasil pada Gambar 2 menunjukkan bahwa ekstrak etanol daun cabai jawa pada konsentrasi $40 \%$ dan antifungi nistatin hanya mampu menghambat pertumbuhan jamur $C$. albicans. Hasil yang menunjukkan bahwa nistatin sebagai kontrol antifungi bersifat fungiostatik (dapat menghambat pertumbuhan $C$. albicans) sesuai dengan hasil penelitian Muriana et al. (2011), dan pada ekstrak etanol daun cabai jawa pada konsentrasi $40 \%$ juga bersifat fungiostatik. Ekstrak etanol daun cabai jawa pada konsentrasi tersebut bersifat fungiostatik karena pada saat ditanam kembali pada media SDA yang baru, baik kontrol antifungi maupun konsentrasi ekstrak etanol, tumbuh koloni jamur $C$. albicans.
Mekanisme kerja antifungi diantaranya adalah dengan menimbulkan gangguan pada membran sel. Gangguan ini terjadi karena adanya ergosterol dalam sel jamur. Ergosterol merupakan komponen sterol yang sangat penting dan sangat mudah diserang oleh antibiotik turunan polien. Kompleks polien-ergosterol yang terjadi dapat membentuk suatu pori dan melalui pori tersebut konstituen esensial sel jamur seperti ion $\mathrm{K}$, fosfat anorganik, asam karboksilat, asam amino, dan ester fosfat bocor keluar hingga menyebabkan kematian sel jamur. Mekanisme kerja antifungi yang lain yaitu dengan menghambat biosintesis ergosterol dalam sel jamur. Mekanisme kerja antifungi tersebut yaitu dengan menimbulkan ketidakteraturan membran sitoplasma fungi dengan cara mengubah permeabilitas membran dan mengubah fungi membran dalam proses pengangkutan senyawa esensial yang dapat menyebabkan ketidakseimbangan metabolik, sehingga menghambat biosintesis ergosterol dari sel jamur (Rochani 2009).

Berdasarkan perbandingan jumlah koloni jamur $C$. albicans yang terbentuk, kemampuan untuk menghambat pertumbuhan jamur uji ekstrak etanol pada konsentrasi 40\% dengan nistatin menunjukkan bahwa nistatin lebih optimal dalam menghambat pertumbuhan jamur uji. Hal ini dikarenakan nistatin merupakan senyawa kimia tunggal sebagai antifungi, sedangkan ekstrak etanol daun cabai jawa hanya berupa hasil maserat yang masih banyak mengandung senyawa kimia lain. Semakin sedikit jumlah koloni jamur yang dihasilkan pada perlakuan ekstrak etanol daun cabai jawa terhadap nistatin dalam uji daya hambat atau daya bunuh maka semakin besar peluang ekstrak menjadi sumber antifungi.

\section{Pengujian golongan senyawa yang bersifat antijamur dengan uji fitokimia/uji tabung}

Pada ekstrak etanol daun cabai jawa dilakukan pengujian golongan-golongan senyawa dengan uji fitokimia. Uji fitokimia dimaksudkan untuk mengetahui golongan senyawa yang terdapat dalam ekstrak yang memiliki aktivitas antijamur. Pengujian dilakukan terhadap senyawa yang ada secara teori dan hasil penelitian sebelumnya sebagai senyawa aktif yang terkandung dalam daun cabai jawa, seperti golongan senyawa alkaloid, saponin, dan flavonoid.

Tabel 4. Hasil pengujian golongan senyawa ekstrak etanol daun cabai jawa

\begin{tabular}{lllc}
\hline $\begin{array}{l}\text { Kandungan } \\
\text { senyawa }\end{array}$ & Teori & Hasil uji & Kesimpulan \\
\hline Alkaloid & $\begin{array}{l}\text { Terbentuknya suatu } \\
\text { endapan }\end{array}$ & $\begin{array}{l}\text { Warna jingga } \\
\text { dan terbentuk } \\
\text { suatu endapan }\end{array}$ & + \\
Saponin & $\begin{array}{l}\text { Adanya buih yang } \\
\text { stabil setinggi } \pm 1 \mathrm{~cm}\end{array}$ & $\begin{array}{l}\text { Terbentuk buih } \\
\text { yang konsisten }\end{array}$ & + \\
Flavonoid & $\begin{array}{l}\text { Tertariknya warna } \\
\text { kuning-merah pada } \\
\text { lapisan alkohol }\end{array}$ & $\begin{array}{l}\text { Terjadi } \\
\text { perbedaan warna } \\
\text { antara lapisan } \\
\text { alkohol dan air }\end{array}$ & + \\
\hline
\end{tabular}

$\overline{\text { Keterangan: + = mengandung golongan senyawa yang dimaksud }}$ 
Ekstrak etanol daun cabai jawa dapat memberikan hasil uji yang positif untuk sebagian besar golongan senyawa yang diujikan. Hal ini dikarenakan senyawa kimia alkaloid, saponin, dan flavonoid bersifat semipolar hingga polar, sehingga dapat larut dalam pelarut etanol $70 \%$ yang merupakan pelarut polar. Beberapa golongan senyawa hasil uji fitokimia ekstrak etanol daun cabai jawa yang memiliki kemampuan sebagai antijamur ditunjukkan pada Tabel 4.

Alkaloid mampu menghambat pertumbuhan mikroba dengan mengganggu sintesis DNA (Cowan 1999). Gugus flavonoid dapat bertindak sebagai antijamur karena mempunyai gugus fenol yang dapat mendenaturasi protein dan merusak membran sel yang bersifat irreversible (tidak dapat diperbaiki kembali) (Pelczar dan Chan 1986). Semakin bersifat lipofilik suatu flavonoid maka akan semakin mudah melekat pada dinding sel jamur dan dapat mengakibatkan kerusakan dinding sel (Walson dan Preedy 2007). Adapun untuk senyawa saponin dapat berfungsi seperti detergen yang dapat berikatan dengan molekul hidrofilik dan molekul-molekul lipofilik (nonpolar), sehingga mampu merusak sel jamur (Mariana et al. 1996).

\section{KESIMPULAN}

Ekstrak etanol daun cabai jawa (Piper retrofractum Vahl.) mempunyai aktivitas penghambatan, pada uji zona hambat menunjukkan aktivitas paling optimal pada konsentrasi 40\%. Ekstrak etanol daun cabai jawa bersifat fungiostatik terhadap pertumbuhan $C$. albicans. Ekstrak etanol daun cabai jawa mengandung senyawa alkaloid, flavonoid, saponin, dan tanin yang berfungsi sebagai antijamur.

\section{DAFTAR PUSTAKA}

Amalia L, Gana SA, Yulinah SE. 2011, Uji Aktivitas Antibakteri dan Antifungi Minyak Atsiri Tanaman Beberapa Suku Piperaceae. Fakultas Farmasi, ITB, Bandung.

Cowan MM. 1999. Plant product as antimicrobial agents. Clinical Microbiology Reviews 12(4): 564-582.

Depkes RI. 1986. Sediaan Galenik. Departemen Kesehatan Republik Indonesia, Jakarta

Harliana D. 2006. Aktivitas Antijamur Ekstrak Rimpang Temu Glenyeh. [Skripsi]. Universitas Sebelas Maret, Surakarta.

Kusuma DF. 2010. Aktivitas Antibakteri Ekstrak Etanol Buah Mengkudu (Morinda citrifolia Linnaeus) Terhadap Bakteri Pembusuk Daging Segar. [Skripsi]. Universitas Sebelas Maret, Surakarta.

Magdalena M. 2009. Candida albicans. Universitas Sumatera Utara Press, Medan.

Muriana, Oesman F, Bahri S et al. 2011. Antifungal activity from side of Cerbera odollan against Candida albicans. Natural 11(1): 11-14.

Nurkanto A. 2010. Eksplorasi mikroba dari tumbuhan marga Piperaceae yang berfungsi sebagai drug discovery senyawa antikanker dan antimikrobakteria. Laporan Akhir Kegiatan Program Insentif Penelitian dan Rekayasa LIPI. Pusat Penelitian Biologi, Lembaga Ilmu Pengetahuan Indonesia (LIPI), Jakarta.

Pelczar MJ, Chan ECS. 1986. Microbiology. McGraw-Hill Book Company, New Delhi.

Pratiwi ST. 2008. Mikrobiologi farmasi. Penerbit Erlangga, Jakarta.

Ridawati, Laksmiejenie BS, Djuwita I. 2011. Aktivitas antifungal minyak atsiri jinten putih terhadap Candida parapsilosis SS25, $C$. orthopsilposis NN14, C. metapsilosis MP27, dan C.etchellsii MP18. Makara Sains 15(1): 56-82.

Rochani N. 2009. Uji Aktivitas Antijamur Ekstrak Daun Binahong (Anredera cordifolia (Tenore) Steen) Terhadap Candida albicans serta Skrining Fitokimianya. [Skripsi]. Universitas Muhammadiyah Surakarta, Surakarta.

Sirait. 2007. Penuntun fitokimia dalam farmasi. Penerbit ITB, Bandung.

Walson RR, Preedy VR. 2007. Botanical medicine in clinical practice. Cromwell Press, Cambridge. 